\title{
NARODOWE W FORMIE, AUTORYTARNE W TREŚCI. BUDOWANIE PAŃSTWA W AZJI CENTRALNEJ
}

WPROWADZENIE

$\mathrm{P}$ o upadku Związku Radzieckiego republiki Azji Centralnej stanęły przed wyzwaniem budowania państwa narodowego z jego symbolami, wyobrażeniami dotyczącymi geografii i geopolityki (np. sporów granicznych), określenia pozycji i roli władzy oraz ludu. Oddolnym procesom odrodzenia narodowego towarzyszyły równolegle podejmowane działania władzy. $\mathrm{Na}$ nurtujące wówczas pytania, kim tak naprawdę byli, są i będą Kazachowie, Kirgizi, Tadżycy, Turkmeni i Uzbecy, władze spieszyły dać stosowną odpowiedź. Przeplatając etnocentryczną interpretację przeszłości, opiewającą glorię i chwałę nacji, z pozostałościami radzieckiego dziedzictwa oraz z elementami zachodnich rozwiązań, wypracowywano nowe mechanizmy.

Niniejszy artykut koncentruje uwagę na procesach etnocentrycznej reinterpretacji przeszłości. Dla nowo powstałych republik, identyfikacja w przeszłości zarówno momentów chwały i mocarstwowości, jak i tragedii była równie silnym argumentem za zajęciem godnego miejsca we wspólnocie narodów. Zadaniem tekstu jest również analiza, jak struktury i instytucje państwa wdrażają lokalne, narodowe rozwiązania. Wynajdywane, konstruowane czy przywracane wartości narodowe odgrywały bowiem kluczową rolę w uzasadnieniu panującej władzy. Autorytarna logika systemu obierała narodową formę. Odwołując się do wielkiego dziedzictwa i bohaterskich przodków, uzyskiwała autentyczność i ustalała siłę swoich związków z suwerenem".

Dr Nartsiss SHUKURALIEVA jest adiunktem w Kujawsko-Pomorskiej Szkole Wyższej w Bydgoszczy. nartsiss7@mail.ru

A. Loomba, Kolonializm/Postkolonializm, tłum. Natalia Bloch, Poznań 2011, s. 194-212; A. Matveeva, Legitimising Central Asian authoritarianism: political manipulation and symbolic power, "Europe-Asia Studies” 61(7), 2009, s. 1095-1121; M. Denison, The Art of the Impossible: Political Symbolism, and the Creation 
Analizowane kraje różnią się między sobą warunkami geograficznymi, politycznymi i gospodarczymi. Mamy tutaj do czynienia z kontrastami dotyczącymi chociażby wielkości terytorium, posiadanych zasobów naturalnych, liczby obywateli, gęstości zaludnienia, poziomu zamożności społeczeństwa. Panujące tu systemy, choć określamy je ogólnie mianem hybrydalnych czy autorytarnych, zajmowały odmienne miejsce także na skali wolności obywatelskich i pluralizmu politycznego.

Z jednej strony mamy do czynienia z Turkmenistanem. Krajem, gdzie stanowiące część krajobrazu złote pomniki prezydenta Turkmenbaszy stały się swoistym symbolem organizacji życia społeczno-politycznego wokół kultu jednostki. Rdzeń ideologii stanowiła prezydencka księga Ruchnama. Wynoszona do rangi świętości wyznaczała symboliczną rzeczywistość kraju. Uczono jej w szkołach, na uniwersytetach, a nawet na kursach prawa jazdy, czy przy weryfikacji kwalifikacji zawodowych. Całkowity brak jakiejkolwiek legalnej opozycji czy wolnych mediów uzupełniają tu cechy państwa izolacjonistycznego. Wedle raportu Freedom House z 2010 r. Turkmenistan znalazł się, obok Korei Północnej, Birmy i Libii, na liście dziewięciu najbardziej represyjnych krajów².

Z drugiej natomiast strony mamy do czynienia z Kirgistanem. Znajdując się na biegunie przeciwnym, w ciągu dwudziestu lat dwukrotnie doświadczył spektakularnego obalenia skorumpowanej władzy (Askar Akajewa i Kurmanbek Bakijewa). Wydarzenia te, znane pod nazwami rewolucji marcowej (2005 r.) i kwietniowej (2010 r.), odzwierciedlaty specyfikę republiki, charakteryzującej się najwyższym $w$ regionie natężeniem organizacji pozarządowych finansowanych przez Zachód. Rządy rodzinne, zawłaszczanie cudzej własności, znane pod nazwą rejderstwo ${ }^{3}$, szykany i zamachy polityczne przeplatały się tu z dyskursem populistycznej demokracji, niekończącymi się protestami społecznymi i głośnymi skandalami medialnymi. Gospodarka rynkowa i stosunkowo wolne media wspótistniały z otwartym lekceważeniem prawa i arbitralnym zarządzaniem państwem. Po wieloletniej turbulencji politycznej w 2010 r. znaleziono kompromis prowadzący do osłabienia instytucjonalnych pełnomocnictw prezydenta i wyłonienia systemu parlamentarnego.

Można wymienić jeszcze wiele różnic występujących w analizowanych pięciu postradzieckich republikach azjatyckich. Niemniej, celem artykułu nie jest ewidencjonowanie odmienności, lecz znalezienie charakterystycznych wspólnych cech dotyczących mechanizmów wykorzystywania wątków narodowych. W jednym kraju mogą one występować bardziej wyraźnie, w innym natomiast mniej. Agresywne i wszechogarniające, czy słabe

of National Identity and Collective Memory in Post-Soviet Turkmenistan, „Europe-Asia Studies” Vol. 61(7), 2009, s. 1167-1187; A. March, From Leninism to Karimovism: Hegemony, Ideology and Authoritarian Legitimation, „Post-Soviet Affairs” Vol. 19, No. 4, 2003, s. 307-334.

2 Wedtug raportu „Freedom House” z 2010 r. Turkmenistan i Uzbekistan, obok Korei Północnej, uzyskały najniższe wskaźniki w dziedzinie wolności obywatelskich i praw politycznych. Patrz: Worst of the Worst 2010. The World's Most Repressive Societies. Selected Data from Freedom in the World, Freedom House's Annual Global Survey of Political Rights and Civil Liberties, Freedom House 2010.

3 Rejderstwo, czyli zajazdy (z ang. raider, początkowo „uczestnik napadu”), to plaga lokalnej gospodarki. Termin ten zaadaptowany z praktyki państw zachodnich, w warunkach postradzieckich miał nieco inne znaczenie. Jeśli początkowo oznaczał legalne, ale jednocześnie moralnie potępiane, przejęcie, fuzje lub wchłonięcie cudzej własności, to później nabrał kryminalnych konotacji. Oznaczał zagarnięcie cudzego przedsiębiorstwa z wykorzystaniem broni, gróźb, szantażu, przemocy, oszustw, defraudacji, czy korupcji w instytucjach państwowych. Odbierano w ten sposób np. przedsiębiorstwa, fabryki, banki, gazety, telewizję, gospodarstwa rolne i ziemię. Wedle danych rosyjskich agencji konsultingowych co roku tylko w Rosji dochodziło do $60-70$ tys. rejderskich nalotów. Zrodzone wraz z procesem prywatyzacji było zwykle domeną grup przestępczych i podmiotów panującej władzy. Uwikłane w nie były także rodziny prezydenckie. Według doniesień prasowych, z działalności rejderskiej były znane np. córka prezydenta Uzbekistanu Gulnara Karimowa, dzieci prezydentów Kirgistanu, Ajdar Akajew i Maksim Bakijek, oraz zięć prezydenta Kazachstanu, Rachat Alijew. Patrz nр.: А. Волков, А. Привалов, Рассуждение о рейдерстве по методе барона Кювье, „Эксперт” nr 18 (559), 2007; Ch. Orozobekova, The Deep Roots of Nepotism in Central Asia, "Radio Free Europe / Radio Liberty USA" 15.12.2010; Г. Марченко, Я ни о каком проекте „Суперхан» не слышал”, интервью Дилярам Аркин, „Свобода слова" 2.12.2010. 
i mniej efektowne, ważny jest sam fakt obecności pewnych zjawisk, stosowanych praktyk i wprowadzanych rozwiązań. Podstawowe pytania badawcze dotyczą kilku kwestii. Jak oficjalna władza reprezentowała przeszłość? Jak budowała ciągłość państwa i narodu? Jaki użytek czerpano z procesów odrodzenia narodowego? Jak narodowe nazewnictwo czy też wynajdywane bądź odtwarzane dawne rozwiązania wiązano ze strukturami nowoczesnego państwa?

\section{W POSZUKIWANIU TOŻSAMOŚCI}

Początek lat dziewięćdziesiątych był czasem odtwarzania państwa narodowego. Wysiłki centralnoazjatyckich elit orientowały się na kształtowanie nowej kultury, tradycji i tożsamości. Zmiana symboliki z komunistycznej na narodową (np. flagi, godła, hymnu) zapowiadała nowy początek, ale i równocześnie kontynuację przeszłych dziejów. Te same intencje towarzyszyły zmianom nazw ulic, wsi i miast (np. stolicy Kirgistanu - Frunze na Biszkek) czy nazwisk (np. prezydenta Tadżykistanu - Rachmonow na Rachmon). Celebrowano nowe święta, przepisywano na nowo historię i ogłaszano nowych bohaterów ${ }^{4}$. Niemniej odcinanie się od kapitału symbolicznego ZSRR nie było tak radykalne, jak by się mogło wydawać na pierwszy rzut oka.

Korzystano na przykład z niektórych wersji prymordialnych interpretacji genezy narodu popularnych również w Związku Radzieckim. Zmieniając niektóre zewnętrzne atrybuty tych koncepcji, nowi ideolodzy nie tylko pozostawali wierni etnocentrycznej interpretacji przeszłości, ale i ją rozbudowywali ${ }^{5}$. Łącząc słownictwo „teorii etnogenezy" z własną konstrukcją ideologiczną, prezydenci nadawali jej status oficjalnego, jedynie prawdziwego poglądu. Im mniej państwo było pluralistyczne, tym większe było jego oddziaływanie. Z jednej strony osiągano to za pośrednictwem wprowadzenia monopolu na prawde (np. w Turkmenistanie i Uzbekistanie). Z drugiej, nie likwidowano relatywnej konkurencji. Drogą przymusu, czy stosunkowo subtelnej perswazji, tworzono nowe ramy pojęciowe, budowano własny system rytuałów i symboli, ale także deprecjonowano alternatywne wobec panującego reżimu wyobrażenia o rzeczywistości. W ten sposób odgórnie konstruowany nacjonalizm stawał się zewnętrzną architekturą pozwalającą podtrzymywać autorytarne treścí.

Zwolennikom „teorii etnogenezy" czasy niepodległości dały nowe życie. Na znaczeniu zyskały prace Lwa Gumilowa, które dotąd były ignorowane przez akademicką kadrę ZSRR, a w najlepszym razie krytykowane za manipulowanie bazą źródłową i „biologizowanie". Po 1991 r. ich wydania były nie tylko kilkakrotnie wznawiane w efektownej okładce,

\section{......}

4 A. Haugen, The establishment of national republics in Soviet Central Asia, New York 2003, s. 109-232; E. Efegil, Authoritarian/Constitutional-Patronage Regimes in Central Asia, "Central Asia and the Caucasus" nr 5(41), 2006, s. 97.

5 Etniczność w ZSRR była tworem politycznym. Ideologia radziecka oraz opierająca się na niej praktyka budowania republik narodowych wiązała ją z jednostką terytorialno-administracyjną. Radziecka "teoria etnosu" opierała się na podejściu prymordialnym, zgodnie z którym konsolidacja etnosu była rozpatrywana jako obiektywny, jednokierunkowy proces.

$6 \quad$ Kierunek tadżyckiej historiografii, podobnie jak w innych republikach centralnoazjatyckich, nadawał prezydent. Przemawiając w lutym 1996 r. na spotkaniu z naukowcami Akademii Nauk Tadżykistanu, E. Rachmon twierdzit, że służbowym obowiązkiem naukowców, ze względu na ich status społeczny oraz ze względu na narodową rolę jest przełamywanie milczenia i reagowanie we właściwym czasie na wszelkiego rodzaju naruszenia interesów narodu i ojczyzny. Patrz np. Э. Рахмонов, Выступление на встрече с учеными академии наук Таджикистана, Февраль 1996, W: Э. Рахмонов, Независимость Таджикистана и возрождение нации. Т. 1, Душанбе 2006, s. 410-416; Б. Алимов, Социально-экономические и политические процессы в Республике Таджикистан (1991-1997г2.). Автореферат диссертации на соискание учёной степени кандидата исторических наук, Худжанд 2008, s. 5-6; С. Абашин, Некоторые размышления после дискуссии о национализме в Узбекистане, „Ab Imperio" nr 4, 2005, s. 294-295. 
ale i zapełniając półki bibliotek i księgarń, stawały się niemal podstawową pozycją w studiach nad historią regionu. Autor, postrzegany jako obrońca kultury i historii, a tym samym dumy narodów turkijskojęzycznych przed stereotypami szowinistycznej historiografii, po śmierci sam stał się obiektem upamiętniania ${ }^{7}$.

Za sprawą prezydenta Kazachstanu Nursultana Nazarbajewa w 1996 r. w stolicy kraju Astanie powstał uniwersytet imienia L. Gumilowa. Na tej uczelni katedra historii i archeologii światowej przekształcona została w katedre badań nad eurazjatyckością. W 2001 r. uzyskała szczególny narodowy status, a rok później otwarto w niej muzeum-gabinet L. Gumilowa. Jednak prezentujący się jako główny ośrodek myśli eurazjatyckiej uniwersytet nie był zainteresowany prowadzeniem badań z prawdziwego zdarzenia. Jego rola miała raczej polegać na konstruowaniu oficjalnej ideologii, a następnie na jej kultywowaniu, promowaniu i wdrażaniu do systemu edukacyjnego ${ }^{8}$. Poziom ideologizacji wyrażał się nie tylko w treści przeprowadzonych konferencji, kongresów, publikowanych materiałów naukowo-dydaktycznych, ale i w samej formie.

Imponująca była architektura budynku uniwersytetu. Składa się z trzech atrium, które miały wyrażać chronologię eurazjatyckości. Pierwsze atrium - Kultegin (dowódca wojskowy z VII-VIII w.) znajdowało się od strony wejścia frontowego. Tutaj sytuowała się kopia pomnika Kultegina, czyli wyrzeźbiony na kamieniu epos opowiadający o heroicznych czynach Kultegin batyra (z jęz. kazachskiego „bohatera”). Drugie poświęcone było L. Gumilowi. Atrium trzecie początkowo prezentowało wystawę etnograficzną. Później, gdy uzyskato miano "Astana", wystawiono w nim makiety nowo wybudowanych budynków stolicy jak np. Ak Orda (tzw. kazachski Belweder), Pałac Niepodległości, lotnisko, Parlament, Stadion Centralny ${ }^{9}$. Jeśli Kultegin reprezentował chwałę dawnych czasów, Astana symbolizować miała modernizację i wielkość dzisiejszego dnia. L. Gumilow, czy jego dopasowana do wymogów oficjalnej polityki teoria, odgrywała kluczową rolę. Wywodziła ona sukces współczesnego Kazachstanu ze zmitologizowanej przeszłości, tworzyła i podtrzymywała dominującą konstrukcję symboliczną mówiącą o tym, jak powinno funkcjonować społeczeństwo. Potwierdzała rację obranej autorytarnej drogi rozwoju, uzasadniała politykę rządu i ukrywała wyłaniającą się dyktaturę za symbolami odrodzenia narodowego. Tym samym, wzmacniała lojalność i solidarność ludzi wobec panującej władzy ${ }^{10}$.

Według etnocentrycznej mitologizacji przeszłości propagowanej w krajach Azji Centralnej naród był przedstawiany jako odwieczna i niezmienna całość. Pojawiały się rozważania dotyczące trwałych, wyróżniających cech, które przybierałyby postać "charakteru narodowego" czy "ducha narodowego". Przymioty te pozwalały stawiać własny naród wyżej w stosunku do innych ${ }^{11}$. Opiewały przodków jako sławnych bohaterów, którzy mieli wnosić wielki wkład do światowej cywilizacji czy uszlachetniać inne narody. Wedle prezydenta Tadżykistanu, Emmomali Rachmona:

-...

7 Np. zbudowany w 2005 r. w stolicy Tatarstanu w Kazaniu pomnik Lwa Gumilova na postumencie zawierał napis "Rosjaninowi [w oryg. русскому человеку], który całe życie bronił Tatarów od oszczerstw". В. Кореняко, Этнонационализм, квазиисториография и академическая наука, w: Реальность этнических мифов, Под ред. А. Малашенко, М. Б. Олкотт, Москва 2000, s. 36-44.

8 Np. projekt badawczy z 2007 r. „Starożytna i średniowieczna Astana jako centrum kulturogenezy stepowej Eurazji” z programu „Idea narodowa”. O działalności katedry badań nad eurazjatyckością szerzej patrz: Кафедра Евразийских исследований http://www.enu.kz/faculty/fsn/chairs/evraziiskih_issledovanii/index.php 21.07.2011.

9 Евразийский национальный университет им. Л.Н. Гумилева- центр евразийской мысли, http://www.enu.kz/ about/evraziisto/ 10.08.2011.

10 D. Kertzer, Rytuat, polityka, władza, tłum. Zygmunt Simbierowicz, Warszawa 2010, s. 66-70.

11 М. Ларюэль, Этнология, национальное становление и политика в Узбекистане, „Ab Imperio" $\mathrm{nr} 4,2005$, s. 287. 
Trzeba szczególnie podkreślić jedną ważną kwestię: walka o wolność, którą ukochała nasza nacja, obecna w społeczno-historycznej postawie, nadaje mu niepowtarzalne cechy. Wyrażają się one w takich ludzkich cechach i wartościach, jak sława, honor, dobroć, męstwo i duma narodowa. I wreszcie, siła nacji opiera się na mądrości i rozumie, szerokim światopoglądzie i cechach twórczych, którymi zawsze się wyróżnialiśmy. Dlatego legendarni synowie nacji tacy, jak Rustam ${ }^{12}$, Sukhrob ${ }^{13}$, Siyavush ${ }^{14}$, odważni przywódcy - Wielki Cyrus ${ }^{15}$, Wielki Dariusz ${ }^{16}$, Spitamenes ${ }^{17}$, Oxyartes $^{18}$, Wielki Kaniszka ${ }^{19}$, Chosroes Anoszirwan ${ }^{20}$, Tahir ibn Husajn ${ }^{21}$, Abd Allah Ibn Tahir22, Jakub Ibn Lajs ${ }^{23}$, Al-Muqanna ${ }^{24}$, Temir Malik25, a w szczególności Ismail Somoni ${ }^{26}$, są wybitnymi przedstawicielami kochającego wolność ducha narodu tadżyckiego. Dzięki ich walce oraz wysiłkom nasza państwowość historycznie uzyskała trwałe moralne i kulturowe podstawy.

W związku z tym, chcę zwrócić uwage na bardzo ważną sytuację, która jeszcze nie otrzymała stosownej oceny badaczy nauk społecznych i historyków. Nasza nacja, rozwijając i wzmacniając swą duchowość narodową, opracowała swoistą kulturę współżycia społecznego, dzięki czemu narody Azji Centralnej zaczęły żyć w atmosferze powszechnego współżycia społecznego i dobrego sąsiedztwa. Zaowocowato to wieloma związkami i przyjaznymi więzami $[\ldots]^{27}$.

Naród był postrzegany jako monolit, pozbawiona wewnętrznych sprzeczności organicystyczna całość. Często był metonimicznie przedstawiany jako jedna bądź wiele postaci. W czasach przeszłych esencję tadżyckości personifikował Ismail Somoni, współcześnie miał ją wyrażać sam prezydent Emomali Rahmon. Taki zabieg był ściśle powiązany z korzystaniem z figury wroga, wykorzystywanego dla wzmacniania wewnętrznej wspólnoty. Wróg mógł mieć charakter historyczny, ale posiadał także swoje współczesne odpowiedniki. Jeśli prezydent był narodem, to wróg prezydenta był postrzegany jako wróg ludu. Taka konstrukcja semantyczna, upraszczając skomplikowane niuanse wydarzeń historycznych, dawała proste odpowiedzi. Pozwalała reprezentować rzeczywistość jako opartą na podziałach dychotomicznych: my - inni, swój - obcy, dobro - zło. Mobilizując naród do bezkompromisowej walki z personifikowanym złem (zwykle utożsamianym z opozycją), mity odwoływały się do obrazów bohaterskich przodków (reprezentowanych przez np. Ismaila Somoni), którzy rzekomo zdolni byli przekazać swym potomkom (np. prezydentowi Emomali Rahmonowi) nadzwyczajną energię i zapewnić zwycięstwo.

\section{- ・ ・ •}

12 Posiadający nadprzyrodzone moce legendarny bohater z eposu "Szahname", autorstwa perskiego poety z X/XI w. Ferdousiego.

13 Sukhrob - syn bohatera Rustama, postać z "Szahname".

14 Siyavush - legendarny książę perski, główny bohater eposu "Szahname”. Mityczne, epickie obrazy Sukhrob, Siyavush i Rustam, które wymienia prezydent, obecne są również we współczesnej literaturze tadżyckiej. Miały one przekazywać ducha dzisiejszego dnia, nadzieje i aspiracje narodu oraz jego pragnienie triumfu sprawiedliwości w zwalczaniu przemocy i ignorancji. Patrz np.: М. Мавлонова, Роль мифов и особенности мифотворчества в современной таджикской прозе (конец XX-начало XXI века). Автореферат диссертации на соискание ученой степени кандидата филологических наук, Худжанд 2007, s. 16.

15 Król Persji z dynastii Achemenidów, ok. 590-529 p.n.e.

16 Władca z dynastii Achemenidów, ok. 550-485 p.n.e.

17 Baktryjski dowódca wojskowy. Walczył przeciwko wojskom Aleksandra Wielkiego, III wiek p.n.e.

18 Baktryjski przywódca, III w. p.n.e.

19 Król Kuszanów, II w.

20 Władca Persji z dynastii Sasanidów, VI w.

21 Założyciel dynastii Tahirydów w Chorasanie, XI w.

22 Władca z dynastii Tahirydów, XI w.

23 Założyciel dynastii Safarrydów, IX w.

24 Przywódca religijny z VIII W., który stał na czele powstania przeciwko kalifowi Al-Mahdi z dynastii Abbasydów.

25 Chan Błękitnej Ordy, XIV w.

26 IX-wieczny władca z dynastii Samanidów, oficjalnie postrzegany jako jeden z założycieli tadżyckiej państwowości.

27 Tłumaczenie własne. Patrz: Э. Рахмонов, Независимость таджикистана и возрождение нации. Т. 5, Душанбе 2006, s. 496. 
Etnocentryczna wizja przeszłości obejmowała kluczowe dla narodu momenty historyczne, z którymi mógł on utożsamiać siebie i swój los. Wizja ta może być analizowana w czterech wymiarach ${ }^{28}$. Po pierwsze, kwestia uzyskania ojczyzny. Wiele kontrowersji wśród historyków wywoływał związek narodu z jego współczesnym terytorium. Chodzi o spory o to, do kogo tak naprawde należą stepy - do Rosjan, Kazachów czy może Kozaków? Czyją kolebką jest Samarkanda i Buchara - uzbecką czy tadżycką? Historiografia każdego z nowych państw Azji Centralnej miała dawać odpowiedź zgodną z jego narodową formułą legitymizacyjną. W ten sposób pozwalała nie tylko uzasadnić roszczenia terytorialne, ale i wzmacniać więź narodu z daną ziemią.

Rozpatrując historię Kazachstanu jako historię Kazachów, prezydent N. Nazarbajew, wielokrotnie powtarzał: „od heroicznych przodków [w domyśle, przodków Kazachów - N. S.], przez wieki broniących Ojczyzny ostrzem swych kopii oraz siłą swych ramion, otrzymaliśmy na wieki w spadku gigantyczny step, który rozpościera się od Atyrau do Ałtaju"29. Podobną retorykę wykorzystywał także prezydent I. Karimow. Według niego, Uzbecy od niepamiętnych czasów zamieszkiwali współczesne terytorium Uzbekistanu. Samarkanda, Buchara i Chiwa od zawsze należały do Uzbeków. Od zawsze także, niezależnie od różnych nazw na przestrzeni dziejów, istniało uzbeckie państwo ${ }^{30}$.

Po drugie, obrazy przeszłości nawiązywały do tworzenia i rozwoju własnej państwowości. Wedle nowej interpretacji, lata 20.-30. XIX w. nie były momentem powstawania centralnoazjatyckich republik narodowych. Przedstawiano je raczej jako jeden z etapów budowy państwowości, istniejącej już od głębokiej starożytności. Państwa te na przestrzeni dziejów miały przeżywać momenty rozkwitu i rozwoju. Nowe interpretacje źródeł historycznych oraz prowadzone badania naukowe, a także najzwyczajniejsza mitologizacja dziejów miały udowadniać naturalny charakter i autentyczność współczesnych republik Azji Centralnej. Stąd pojawiał się termin „odrodzenie”, gdyż państwo jedynie miało odkrywać własną przeszłą chwałę. Powołując się na nią w teraźniejszości i ustalając jej związki z aktualnym stanem, sugerowano, że kryzysowy okres przejściowy w naturalny sposób zakończy się restytucją odwiecznej świetności.

Podstawę oficjalnej tezy o starożytnym rodowodzie kirgiskiej historii i państwowości czerpano z powstałych w latach 109-91 p.n.e. kronik chińskiego historyka Sima Qiana pt. Zapiski historyczne ${ }^{31}$. Powołując się na nie, prezydent Askar Akajew inicjował obchody 2200-lecia kirgiskiej państwowości. Obchodzone w sierpniu 2003 r. uroczystości jubile-

\section{......}

28 В. Шнирельман, Ценность прошлого: этноцентристские исторические мифы, идентичность и этнополитика W: Реальность этнических мифов, Под ред. А. Малашенко, М. Б. Олкотт, Москва 2000, s. 18.

29 Patrz nр.: Выступление Президента Республики Казахстан Н.А. Назарбаева на III Всемирном курултае казахов, Астана, 29 сентября 2005 года, w: Президент Н.А. Назарбаев и современный Казахстан. Сборник документов и материалов в трех томах. Т. ІІ: Н.А. Назарбаев и Казахстанская стратегия политических реформ, Алматы 2010, s. 219; Н.А. Назарбаев, К экономике знаний через инновации и образование. Из лекции в Евразийском национальном университете им. Л.Н. Гумилева. Астана, 25 мая 2006 г., W: Президент Н.А. Назарбаев и современный Казахстан. Сборник документов и материалов в трех томах. Т. І: Н.А. Назарбаев и социальноэкономическое развитие Казахстана, Алматы 2010, s. 186.

30 И. Каримов, Без исторической памяти нет будущего, ш: И. Каримов, Свое будущее мы строим своими руками. Т. 7, Ташкент 1999, s. 128-151.

31 Powołując się na Sima Qiana, A. Akajew twierdzit, że „w 201 r. p.n.e. wódz Hunów Szaniuj Mote zdobył i dołączył do swego państwa wraz z ziemiami innych ludów posiadłości Kirgizów”. Według prezydenta słowo zdobyć miało znaczyć, że u starożytnych Kirgizów istniał system, który historycy mają prawo zaklasyfikować jako państwowość. Wynikać to miało ze zdolności do stawiania oporu zewnętrznym zagrożeniom, którą wykazywali Kirgizi. Z inicjatywy A. Akajewa Zgromadzenie Ogólne ONZ ogłosiło rok 2003 rokiem 2200-lecia kirgiskiej państwowości. Zob. Resolution adopted by the General Assembly [on the report of the Second Committee (A/57/531/Add.3)] 57/248. Year of Kyrgyz Statehood, 78th plenary meeting, 20 December 2002; А. Акаев, Кыргызская государственность и народный эпос „Манас”, Бишкек 2002, s. 16. 
uszowe na centralnym placu stolicy rozpoczynała defilada wojskowa. Następnie przedstawiono publiczności inscenizacje historii Kirgizów. Finałem uroczystości był pochód przedstawicieli przedsiębiorców oraz czterech rejonów Biszkeku. Na wieczór władze przygotowały potężny pokaz fajerwerków, a na górze Bajtik oddano salwy ${ }^{32}$.

Po trzecie, wspominano o wielkich podbojach i mocarstwowości. Było to logiczną kontynuacją analizowanej powyżej etnicznej mitologizacji procesów budowania własnej państwowości w pradawnych czasach. Łącząc pokrewne starożytne ludy pod własnym imieniem i inkorporując do własnej państwowości, nacjonalizowano świadectwa historyczne. Obchodzono święta narodowe upamiętniające zamierzchłą potęgę i pradawność państwowości, pisano książki i organizowano konferencje naukowe. Nowa władza-wiedza, organizując system edukacyjny, wpływając na rekrutację do organów władzy oraz porządkując symboliczną przestrzeń, miała wszystkie narzędzia dla konstruowania nowej narodowej rzeczywistości. Mity o bohaterskiej przeszłości, wielkich przodkach i chwale, oprócz uzasadniania panującej władzy w teraźniejszości, pełniły także ważną funkcję kompensacyjną. Były źródłem dumy i poczucia narodowej wartości, pozytywnie wzmacniały samoocenę W rzeczywistości, w której degradujące się pozostałości systemu radzieckiego (infrastruktura, system emerytalny, zdrowotny, edukacyjny, rolniczy, przemysłowy itd.) zastępowały nieefektywne instytucje nowego jednak państwa. W ten sposób dumę z bycia przedstawicielem jednego z najpotężniejszych krajów na świecie, ZSRR, próbowano zastąpić porównywalnie wielkim odpowiednikiem znalezionym w przeszłości i mozolnie odbudowywanym w teraźniejszości ${ }^{33}$.

Stąd na przykład o niegdysiejszej tadżyckiej mocarstwowości miały świadczyć imperia starożytnego Iranu. O potędze Uzbeków świadczyło rozciągające się od Morza Czarnego do Indii imperium Tamerlana (XIV-XV w.). Natomiast prezydent Turkmenistanu Saparmurat Nijazow w księdze „Ruchnama" twierdzit:

[...] Początki swojej historii wywodzimy z epoki założyciela nacji Oguz Chana Turkmena, który żył pięć tysięcy lat temu. Spoglądając na odległą historię, Turkmeni wielokrotnie ukazywali światu swoje prawdziwe przeznaczenie, tworząc wspaniałe duchowe i materialne wartości, które stały się integralną częścią starożytnych cywilizacji od Indii do Morza Śródziemnego. Tylko na własnych ziemiach, zbudowali ponad 70 państw! Są wśród nich owiane światową sławą: Änew ${ }^{34}$, Altyn-Depe ${ }^{35}$, Margiana ${ }^{36}$, Partia $^{37}$, imperium Turkmen - Seldżuków ${ }^{38}$, państwa Turkmenów Kunya Urgench ${ }^{39}$.

32 Typowe dla republik Azji Centralnej było wykorzystywanie odwołań do wielkiej chwały dla odwrócenia uwagi czy tuszowania bieżących decyzji sprzyjających uzurpacji władzy. Stąd nie było przypadkiem ogłoszenie 2003 roku rokiem 2200-lecia kirgiskiej państwowości oraz organizacja obchodów. Wydarzenia te szły w parze ze wzmacnianiem władzy prezydenckiej, gdyż przygotowaniom do jubileuszu towarzyszyła równolegle nowelizacja Konstytucji. Zgodnie z wprowadzonymi zmianami i uzupetnieniami, organizowanie pokojowych wieców i pochodów możliwe było tylko za zgodą władz. Ustawodawca, usuwając z Konstytucji pojęcie „wolności prasy" (art. 16), równocześnie wprowadził autorytarne rozwiązania do rozdziału dotyczacego praw i wolności człowieka. Patrz np.: Киргизия празднует 2200-летие государственности, „Кабар” 31.08.2003; Кыргыз Республикасынын Конституциясы, Кыргыз Республикасынын он экинчи шайланган ЖК он экинчи сессиясында 1993-жылдын 5-майында кабыл алынган, Кыргыз Республикасынын 2003-жылдын 2-февралындагы референдумда кабыл алынган „Кыргыз Республикасынын Конституциясынын жаны редакциясы жөнүндөгү” мыйзамында баяндалган, кара: „Эркин-Тоо” 21.02.2003.

33 I. Pańków, Mity w działaniach politycznych, "Studia Nauk Politycznych” nr 5-6(59-60), 1982, s. 135-139.

34 Miasto w Turkmenistanie, gdzie pierwsze ślady obecności człowieka w regionie pochodzą z III w. p.n.e.

35 Jedno z pierwszych w regionie miast z epoki brązu (III w. p.n.e.), leżało na południowym zachodzie współczesnego Turkmenistanu.

36 Starożytne państwo, znajdowało się we wschodniej części współczesnego Turkmenistanu.

37 Partia (z ang. Parthia, 247 r. p.n.e. - 224 r. n.e.) starożytne państwo leżące na ziemiach dzisiejszego północno -wschodniego Iranu i Turkmenistanu.

38 Dynastia, uznawana przez oficjalną historiografię za Turkmenów. Panowała w różnych krajach Azji Zachodniej i Centralnej w XI-XIV w.

39 Tłumaczenie własne. Patrz: С. Ниязов, Рухнама, Ашхабад 2002, s. 10. 
Budując narracje o minionych wielkich podbojach i mocarstwowości Turkmenów, władza szła jeszcze dalej, ogłaszając XXI wiek - złotym wiekiem narodu turkmeńskiego. Podczas gdy w bratnich republikach nadejście utraconego złotego czasu projektowano w nieokreśloną przyszłość, rządy S. Nijazowa były już w zasadzie na ich progu. Taki zabieg temporalny wiązał się ściśle z sakralną legitymizacją władzy. W ramach tej formuły prezydent miał boską rzekomo moc, księga jego autorstwa „Ruchnama” ogłoszona została świętą, a czasy, w których panował, miały być porównywalne do raju. Teraźniejszym odpowiednikiem dawnych „podbojów” było ogłoszenie neutralności państwa i pokojowe nastawienie wobec świata. Z kolei "mocarstwowość” wyrażała się nie tylko W uznaniu społeczności międzynarodowej, ale nawet w „podziwie” dla turkmeńskiej polityki. Pozytywnej, wręcz apologetycznej ocenie przeszłości, odpowiadała podobna percepcja teraźniejszości ${ }^{40}$.

Po czwarte, narracja obejmowała wątki katastroficzne i kryzysogenne, które przerwaty trajektorię rozwoju danego narodu. Mimo sprzeczności i kontrastu z poprzednio omawianymi wątkami o uzyskaniu ojczyzny, o formowaniu państwa i jego mocarstwowości, były one równie silnym argumentem za zajęciem godnego miejsca we wspólnocie narodów. Wspólnota żalu dotyczącego przeszłości i razem przebyte cierpienia, według E. Renana, jednoczyć mogą naród nawet bardziej niż wspólna radość. Żałoba czy pamięć o tragedii narodowej była warta więcej niż triumf. Takie stany nakładają bowiem obowiązki i domagają się wspólnego wysiłku. Przeszłe poświęcenia wytwarzać miały solidarność w teraźniejszości, aby przez ponowne poświęcenie doprowadzić do narodowego odrodzenia ${ }^{41}$.

Dramatyczny los Tadżyków był tematem wielu tekstów. Tytuły takich książek, jak Ta-

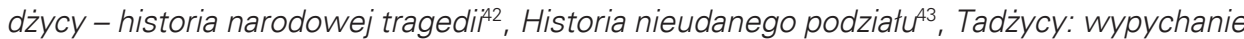
i asymilacja ${ }^{44}$, Tadżykistan: tragedia i ból narodu ${ }^{45}$ mówią same za siebie. Wedle Rahim Masova ${ }^{46}$ po upadku państwa Samanidów w życiu Tadżyków nastąpiły trudne czasy. Tadżycy nie tylko stracili swoją narodową państwowość, niezawisłość, ale stali się narodem na wygnaniu, narodem bez prawa, czy nawet narodem - niewolnikiem despotycznych reżimów. Stało się tak wskutek agresji oraz napadów ze strony turkijsko-mongolskich plemion, a później wypychania z terytorium oraz procesów asymilacji. Od czasów późnego średniowiecza do współczesności doświadczając podziału terytorialno-ekonomicznego oraz kulturowego, poniżenia, będąc pozbawionymi praw i stale prześladowanymi, znaleźli się na granicy całkowitej zagłady fizycznej. Mimo tych procesów nie tylko przetrwali, zachowali swój język i kulturę, ale także wywarli duży wpływ na inne narody. Początki niepodległości, po upadku ZSRR, okazały się dla Tadżykistanu równie dramatyczne. W latach 1992-1997 rozgorzała wojna domowa. Jednak i tym razem w rozwijanej narracji gloryfikującej wolę przetrwania, Tadżycy mieli się podnieść, ponownie stanąć na drodze odrodzenia, jedności i wzrostu ekonomiczno-kulturowego ${ }^{47}$.

40 D. Kertzer, op. cit., s. 59; T. Edensor, Tożsamość narodowa, kultura popularna i życie codzienne, tłum. Agata Sadza, Kraków 2004, s. 34.

41 E. Renan, Co to jest naród, ttum. Michał Warchał, "Res Publica Nowa”, zima 2005 r., s. 143.

42 Р. Масов, Таджики: история национальной трагедии, Душанбе 2008.

43 Р. Масов, История „топорного” разделения, Душанбе 1991

44 Р. Масов, Таджики: вытеснение и ассимиляция, Душанбе 2003.

45 Г. Хайдаров, М. Иномов, Таджикистан: трагедия и боль народа, Санкт-Петербург 1993.

46 Rahim Masov - profesor, członek rzeczywisty akademii, dyrektor Instytutu Historii, Archeologii i Etnografi im. A. Donisza Akademii Nauk Tadżykistanu.

47 Р. Масов, Таджики: вытеснение и ассимиляция, s. 5-11. 
Po otrzymaniu niepodległości w krajach Azji Centralnej rozpadające się struktury radzieckie nie zostały zastąpione przez sprawnie funkcjonujące instytucji państwowe. Początkowe deklaracje przekształcenia istniejącego systemu wedle wzorów zachodniej demokracji, wprowadzenia rządów prawa i wolnego rynku się nie ziścity. W pierwszych latach niepodległości odgrywały one funkcję swoistego zaklęcia uświęcającego obrzędy przejścia od stanu zależnego od Moskwy do niezawisłości. W rzeczywistości, obudowując się układami nieformalnymi o różnej logice systemy polityczne posługiwały się podwójną (formalną i nieformalną), wewnętrznie sprzeczną metodą regulacji życia społeczno-politycznego ${ }^{48}$. W mocno spersonalizowanych realiach prezydenci, mimo oficjalnych ograniczeń kadencyjnych, trwale zajmowali swoje stanowiska. Wymowne są tutaj przykłady niezmiennie rządzących od ponad dwudziestu lat Nursułtana Nazarbajewa w Kazachstanie czy Islam Karimowa w Uzbekistanie. Zmiana władzy dokonywała się w regionie jedynie w drodze naturalnej śmierci (Turkmenistan), wojny domowej (Tadżykistan) czy tak zwanej rewolucji (Kirgistan). Wsparte na woli polityczno-ekonomicznej prezydentów porządki prawne wspótistniały z systemami arbitralnych decyzji oraz dyskrecjonalnym kierowaniem państwem.

Podstawą prawną powstających systemów politycznych republik Azji Centralnej miały być nowe konstytucje. Wzorując się na modelu zachodnich demokracji głosity one prymat praw człowieka, gwarantowały własność prywatną i zatwierdzały zasadę trójpodziału władzy na ustawodawczą, wykonawczą i sądowniczą. Prezydent oraz deputowani parlamentu byli wybierani w wyborach bezpośrednich i tajnych, a ich pozycję ograniczała kadencyjność. Konstytucje zawierały także odwołania do wątków narodowych. Parlament w Kirgistanie obrał nazwę Dżogorku Kenesz, w Uzbekistanie - Oliy Majlis, w Tadżykistanie Madżlisi Oli, w Turkemnistanie - Mejlis, w Kazachstanie jedna z izb parlamentu - Mażylis ${ }^{49}$.

Akty prawne odwoływały się do lokalnych zwyczajów, np. art. 26 pkt 3 kirgiskiej konstytucji stwierdzał, że szacunek do starszych, opieka nad krewnymi i bliskimi jest świętą tradycją narodu Kirgistanu. Nawiązanie do narodowych archetypów widoczne było również w art. 55 pkt 2, zgodnie z którym pierwsze posiedzenie parlamentu Dżogorku Kenesz otwierał najstarszy pose ${ }^{50}$. W Turkmenistanie, na przykład, obok parlamentu Medżlis (do 2008 r.) funkcjonował równoległy organ przedstawicielski Rada Ludowa, czyli Chalk Maslachaty. Według prezydenta Gurbanguly Berdimuchamedova nie powstał on w próżni, lecz był pradawną narodową tradycją. Zwoływanie zjazdu przedstawicieli ludu dla przyjęcia ważnych dla wspólnoty decyzji miało mieć u Turkmenów tysiącletnią historię. Ta metoda naradzania się z najbardziej szanowanymi przedstawicielami ludu była umiejętnie

......

48 J. Staniszkis, Postkomunizm. Próba opisu, Gdańsk 2001, s. 9-22.

49 Zgodnie z art. 44, 50 i 51 Konstytucji Kazachstanu na mocy noweli z 2 lutego 2011 r. Mażylis liczy 107 członków wybieranych na pięcioletnią kadencję. Dziewięćdziesięciu ośmiu z nich było wybieranych na podstawie powszechnego, równego i bezpośredniego prawa wyborczego w głosowaniu tajnym. Dziewięciu deputowanych Mażylis było wybieranych przez Zgromadzenie Narodów Kazachstanu - organ powoływany przez prezydenta. Patrz: Қазақстан Республикасының Конституциясы. 1995 жылғы 30 тамызда республикалық референдумда қабылданды. Республикалық референдум нәтижесі жарияланған күні, яғни 1995 жылғы 5 қыркүйекте күшіне енді. Қазақстан Республикасының 1998 жылғы 7 қазандағы Заңымен, Қазақстан Республикасының 2007 жылғы 21 мамырдағы Заңымен, Қазақстан Республикасының 2011 жылғы 2 ақпандағы Заңымен өзгерістер мен толықтырулар енгізілген.

50 Konstytucja Kirgiskiej Republiki według noweli z 2003 r. Кыргыз Республикасынын Конституциясы, op. cit.; Podobne rozwiązanie przewidywał również art. 52 konstytucji Tadżykistanu według noweli z 2003 r. Patrz: Конституция Республики Таджикистан, Принят на всеобщем референдуме 6 ноября 1994 года, Внесены изменения и дополнения в результате референдума от 26 сентября 1999 года, Внесены изменения и дополнения в результате референдума от 22 июня 2003 года. 
wykorzystana w pierwszych latach niepodległości dla podtrzymywania niedemokratycznej władzy. Jednocześnie prezydent opisywał ją jako efektywną metodę dochodzenia do ogólnonarodowej zgody ${ }^{51}$. W ten oto sposób, splatając elementy narodowe z niektórymi rozwiązaniami systemów zachodnich, dopasowywano akty prawne do oczekiwań lokalnych elit oraz wynajdywano i tworzono własne, ułatwiające dominację mechanizmy. Można je rozpatrywać $w$ trzech wymiarach.

Po pierwsze, polegały one na nacjonalizacji idei sprawiedliwego państwa. Stąd określenia takie jak „samodzielna droga rozwoju” 52 , które podkreślały oparcie państwa na lokalnych wartościach. Również ideały demokratyczne, ogłaszane jako odwieczne dążenia ludu, czy pochodzące z dziedzictwa przodków, miały mieć charakter narodowy. Według I. Karmowa,

Od niepamiętnych czasów, Uzbecy walczyli, żeby móc myśleć i żyć samodzielnie, być wolnym i niezależnym [...] ta konstytucja w każdym swoim artykule, w swoich podstawowych zasadach odzwierciedla myślenie narodowe i ponadczasowe wartości islamu które ukształtowały się jeszcze za czasów Chodża Ahmad Jasawiego, wielkiego Emir Timura i Timuridów ${ }^{53}$.

Po drugie, ustalanie związków narodu i systemu politycznego wiązało się z zawłaszczaniem pojęcia nacji. Władza, określając wiedze o historii narodowej, kulturze czy wartościach, definiowała porządek dominacji w teraźniejszości. Na przykład w Uzbekistanie, choć art. 11 konstytucji deklarował trójpodział władzy ${ }^{54}$, równocześnie miały one funkcjonować jako nierozdzielny związek. I. Karimow twierdzit:

Z wielką satysfakcją chce powiedzieć jeszcze jedno: w innych krajach, przede wszystkim w Rosji [reprezentującej w tym przypadku Zachód, i monteskiuszowskie zasady podziału i równowagi władzy - N.S.], prezydent, rząd i parlament pozostają ze sobą w konflikcie, rywalizując o autorytet. Nasze natomiast najwyższe organy władzy wykonują swoje obowiązki wobec ludu w przyjaźni i harmonii 55 .

W ten oto sposób ideał politycznego myślenia, wyrażający się W określeniu „jednomyślność i zgoda ludzi - to wielkie zwycięstwo dla nas wszystkich" ${ }^{56}$, nie przewidywał istnienia konfliktu jako naturalnego komponentu w relacjach społecznych. Domagając się wtopienia w oficjalnie akceptowany główny nurt, wykluczał jakąkolwiek możliwość krytyki czy opozycji wobec panującego reżimu.

Po trzecie, wszystko to, co było krytyczne wobec panującej rzeczywistości, zdefiniowane zostało jako „inne”. Każdy, kto nie wpisywał się w odgórnie ustanawiany zespół narodowych wyobrażeń kulturowych, rozumiany jako akceptujący status quo, mógł zostać zdefiniowany jako podejrzany czy stwarzający zagrożenie dla bezpieczeństwa narodowego. W takim systemie założeń akty protestu nie mogły być postrzegane jako pochodzące od ludu, lecz miały mieć związki z obcymi siłami, rewolucjonistami, terrorystami i fundamentalistami religijnymi. Powyższe określenia, organizujące dyskursy o bezpieczeństwie w krajach zachodnich zwłaszcza po 11 września 2001 r., znalazły w Uzbekistanie wyjątkowo żyzną glebę. O terroryzm oskarżony został na przykład prezes opozycyjnej partii "Erk",

\section{.....}

51 Г. Бердымухамедов, Закон должен служить человеку, http://www.turkmenistan.ru/ru/node/24828, 17.10.2008

52 Собственный путь развития, Информационное агентство «Жахон» при МИД Республики Узбекистан, 05.12.2009.

53 И. Каримов, Правовая гарантия нашего великого будущего, w: И. Каримов, Наша цель: свободная и процветающая Родина, Ташкент 1996.

54 Конституция Республики Узбекистан. Принята 8 декабря 1992 года на одиннадцатой сессии Верховного Совета Республики Узбекистан двенадцатого созыва. В настоящую Конституцию внесены изменения в соответствии с Законом РУз от 18.04.2011 г. Nr 3Ру-284.

55 И. Каримов, Узбекистан - государство с великим будущим, W: И. Каримов, Узбекистан: национальная независимость, экономика, политика, идеология, Ташкент 1996.

56 И. Каримов, Основные принципы общественно-политического и экономического развития Узбекистана W: И. Каримов, Родина священна для каждого, Ташкент 1995. 
znany uzbecki poeta oraz główny rywal I. Karimowa w wyborach prezydenckich z 1991 r. - Muchammad Solih. Oficjalnie świadectwem ich obecności były wybuchy w Taszkencie (1999 i 2004 r.), w Bucharze (2004 r.), wydarzenia w Andiżanie (2005 r.). Niezliczone osoby zatrzymane i aresztowane miały tylko uzasadniać tezę o konfliktogennym potencjale regionu i niezbędności rządów twardej ręki.

PODSUMOWANIE

Zadaniem moim było prześledzenie wybranych mechanizmów towarzyszących procesom odrodzenia narodowego w republikach Azji Centralnej po upadku Związku Radzieckiego. Mówiąc precyzyjniej, chodziło o analizę działań podejmowanych przez władze, które odwołując się do wątków narodowych, legitymizowały siebie, ale i sterowały procesami budowania świadomości narodowej. Pytanie bardziej szczegółowe dotyczyło tego, jakie wyobrażenia tworzyły tamtejsze struktury państwowe, gdy mowa o przeszłości i definiowaniu teraźniejszości. Celem artykułu nie było jednak analizowanie efektywności konstruowanej przez władzę ideologii ani ocena stopnia ich przyjmowania czy odrzucania przez podporządkowane podmioty.

Popularyzowana przez autorytarne rządy "teoria etniczna” była elastycznym budulcem dla alternatywnej wobec radzieckiego marksizmu interpretacji historii. Zastępując podmioty klasowe etnicznymi, stawała się funkcjonalna dla politycznych potrzeb nowej elity. Mitologizowana przeszłość narodu zawierała narracje o uzyskaniu ojczyzny, o formowaniu państwa, o jego mocarstwowości oraz wątki katastroficzne - pogrążając naród w wielkiej tragedii, jednocześnie wzmacniała go wobec nowych wyzwań. Mimo sprzeczności i kontrastów wątki te były silnym argumentem za zajęciem godnego miejsca we wspólnocie narodów. Wyjaśniając nieunikniony rozpad ZSRR, uzasadniały powstanie nowych państw w Azji Centralnej. Odrodzenie narodowe miało również uzasadniać autorytarne rządy. Stąd, definiowana przez władze kultura, zwyczaje i wartości narodowe miały sprzyjać zachowaniu status quo. Dotyczyło to zarówno tworzenia porządku administracyjno-prawnego, jak i wyobrażeń na temat zachowania społecznego - tego, co jest autentycznie uzbeckie, turkmeńskie, kirgiskie, kazachskie i tadżyckie.

Działania władzy nie były jednak przyjmowane przez społeczeństwa bezkrytycznie. W przypadku bardziej liberalnych krajów mamy do czynienia z rozmaitymi formami protestu, jak polemiczne wobec rządu artykuły prasowe, organizowanie antyrządowych happeningów, blokady ulic czy bunt wobec organów przymusu. W innych, brak pluralizmu ekonomiczno-społeczno-politycznego i ostre represje utrudniały czy wręcz uniemożliwiały otwarty sprzeciw. Likwidowano tu wszystko, co stwarzało realne zagrożenie dla systemu. Zaś symboliczną rzeczywistość tworzyły ostentacyjne wyrazy lojalności wobec prezydenta - twórcy i wyraziciela interesów narodu. 


\section{Summary}

After the collapse of the Soviet Union the new states of Central Asia faced a challenging task of building a new country, its symbols, relations between institutional power and the sovereign and imaginary geopolitical landscape. The grass root processes of national awakening were coupled with the deliberate activities of the dominant political actors striving to shape them in a way conducive to their power claims. Thus the monuments of great ancestors and the billboards presenting the image of incumbent presidents became very common element of the symbolic landscape of Central Asia's new republics. The official speeches of the governing presidents have frequently referred to great historical figures, constructed historical analogies, praised the thousand years old traditions of the fatherland and adduced historical evidence testifying ancient roots of the countries.

This article is focused on the mechanisms of ethnocentric reinterpretation of the past. For the newly constituted Republics of Central Asia either the evidence of the past power status and glorious moments or of the past tragedies have been equally strong legitimizing factors both internally and externally. No matter, whether invented or constructed, propagated national values have played a key role in justifying the power claims and international position of the new countries. Additionally, the paper's objective is to analyze how state structures and institutions implement national solutions and how the authoritarian logic of the state institutions performed its power under the guise of national forms.

Keywords: Central Asia, Kyrgyzstan, Kazakhstan, Uzbekistan, Tajikistan, Turkmenistan, authoritarianism, nationalism, legitimization 